九州大学学術情報リポジトリ

Kyushu University Institutional Repository

\title{
Synopsis of Andrena (Micrandrena) of Japan (Hymenoptera, Andrenidae) Part I
}

Tadauchi, 0samu

Entomological Laboratory, Faculty of Agriculture, Kyushu University

https://doi.org/10.5109/23813

出版情報: 九州大学大学院農学研究院紀要. 30 (1)，pp.59-76，1985-09. Kyushu University バージョン：

権利関係 : 
J. Fac. Agr., Kyushu Univ., 30(1), 59-76 (1985)

\title{
Synopsis of Andrena (Micrandrena) of Japan (Hymenoptera, Andrenidae) Part I*
}

\author{
Osamu Tadauchi \\ Entomological Laboratory, Faculty of Agriculture, \\ Kyushu University 46-01, Fukuoka 812 \\ (Received May 21, 1985)
}

\begin{abstract}
The subgenus Micrandrena Ashmead of the genus Andrena of Japan is revised and eleven species are recognized. Five of them are new to the Japanese fauna. In this paper (Part I) seven species are treated, including two new species, Andrena (Micrandrena) munakatai and A. (Micrandrena) hanedai. The male of A. (Micrandrena) falsificissima Hirashima is described for the first time. The distributional map, floral records, and flight records of each species are presented.
\end{abstract}

\section{INTRODUCTION}

The subgenus Micrandrena of the genus Andrena constitutes many, tiny species. It is characterized by the 1 st transverse cubital vein ending very close to the pterostigma, the entire process of the labrum, the incomplete propodeal corbicula and so on. It distributes in both the New and Old Worlds. Lanham (1949). and Ribble (1968) studied the subgenus of the New World, and Hedicke (1933) and Warncke (1968) treated this subgenus in the subgeneric classification of the west Palearctic Region.

In Japan, Hirashima (1965) recorded four species, and later in 1966, he added two more species to her fauna of the subgenus. However, a detail, comparative study remained based on enough specimens, because it seemed to include a few more closely related species and seasonal forms. In the present study I examined 10,976 specimens (9,372 females and 1,604 males) of the subgenus collecting from throughout Japan and recognized eleven species. Out of them 3 species are new to science. A. (Micrandrena) minutula (Kirby) is the first record and A. (Micrandrena) subopaca Nylander may be a real record from Japan, respectively. The minutula-group in Japan is composed of four species in all, which are very similar with one another. The male of $\mathbf{A}$. (Micrandrena) falsijcissima Hirashima is firstly described.

\section{Subgenus Micrandrena Ashmead, 1899}

Micrandrena Ashmead, 1899, Trans. Amer. ent. Soc., 26: 89; Lanham, 1949,Univ. Calif. Pub.

* Contribution from the Entomological Laboratory, Faculty of Agriculture, Kyushu University, Fukuoka (Ser. 3, No. 175). 
Ent., 8: 208; Hirashima, 1965, J. Fac. Agr., Kyushu Univ., 13: 461; Ribble, 1968, Bull. Univ. Neb. St. Mus., 8: 237; Warncke, 1968, Mem. Est. Mus. Zool. Univ. Coimbra, (308): 58.

Andrenella Hedicke, 1933, Mitt. zool. Mus. Berlin, 19: 210.

\section{Andrena (Micrandrena) hikosana Hirashima}

Andrena (Micrandrena) hikosana Hirashima, 1957, Mushi, 30: 53, female; Hirashima, 1965, J.

Fac. Agr., Kyushu Univ., 13: 462, female and male; Hirashima, 1966, J. Fac. Agr., Kyushu Univ., 14: 94 and 117; Kim and Kim, 1983, Kor. J. Ent., 13: 7.

This species is distributed in all over Japan and prefers to visit the blossoms of the Aceraceae.

Distribution : Japan (Hokkaido, Honshu, Sado Is., Shikoku, and Kyushu) (Fig. 6), and Korea.

Floral records: This species has been collected on 23 plants as follows: Rosaceae: Prunus armeniaca L. (22 females and 20 males); P. salicina Lindl. (1 female and 10 males) ; P. persica Batsch. (1 female) ; Malus pumila Mill. (1 female) ; Pyrus pyrifolia var. culta Nakai (1 female) ; Crataegus cuneata Sieb. et Zucc. (4 females) ; Potentilla kleiniana subsp. anemonefolia Murata (5 females) ; P. fruti$\cos a$ L. (2 females) ; Photina glabra Maxim. (21 females). Compositae :Taraxacum japonicum Koidz. (1 female) ; T. officinale Weber (5 females and 4 males) ; Lapsana apogonoides Maxim. (2 females). Cruciferae: Brassica napus L. (25 females and 28 males) ;Cardamine leucantha 0. E. Schulz (1 female);Capsellabursapastoris Medic. (2 females). Leguminosae :Astragalus sinicus L. (1 female). Salicaceae: Salix spp. (15 females and 13 males). Aceraceae: Acer sp. (165 females and 16 males). Umbelliferae :Heracleum lanatum subsp. moellendorffi Hara (1 female). Ranunculaceae : Cimicifuga simplex Wormsk. (2 females). Saxifragaceae: Deutzia crenata Sieb. et Zucc. (2 females). Celastraceae : Euonymus alatus Sieb. (11 females). Violaceae :Viola kusanoana Makino (1 female).

Flight records: Females fly from mid April to early June in Kyushu, and from mid May to late June in Hokkaido. Males have been collected from late March to mid May in Kyushu, and from early to mid May in Hokkaido.

Specimens examined: I have examined 559 females and 157 males from Hokkaido, Honshu, Sado Is., Shikoku, and Kyushu. Some records from Shikoku are cited as follows: 1 male, Ochiai, Kuma, Ehime Pref., 15. iv. 1976 (0. Tadauchi) ; 1 female, Sadamitsu, Tokushima Pref., 17. iv. 1976 (0. Tadauchi).

\section{Andrena (Micrandrena) falsificissima Hirashima}

Andrena (Micrandrena) falsificissima Hirashima, 1966, J. Fac. Agr., Kyushu Univ., 14: 92, female, and 95.

This species described based on a short series of female specimens collected at Sugadaira, Nagano Pref., in central Honshu. In the present study, I could examine 17 females and 4 males from Hokkaido and central Honshu (Niigata and Fukui Prefs.).

The description of male, which is new to science is given below. 

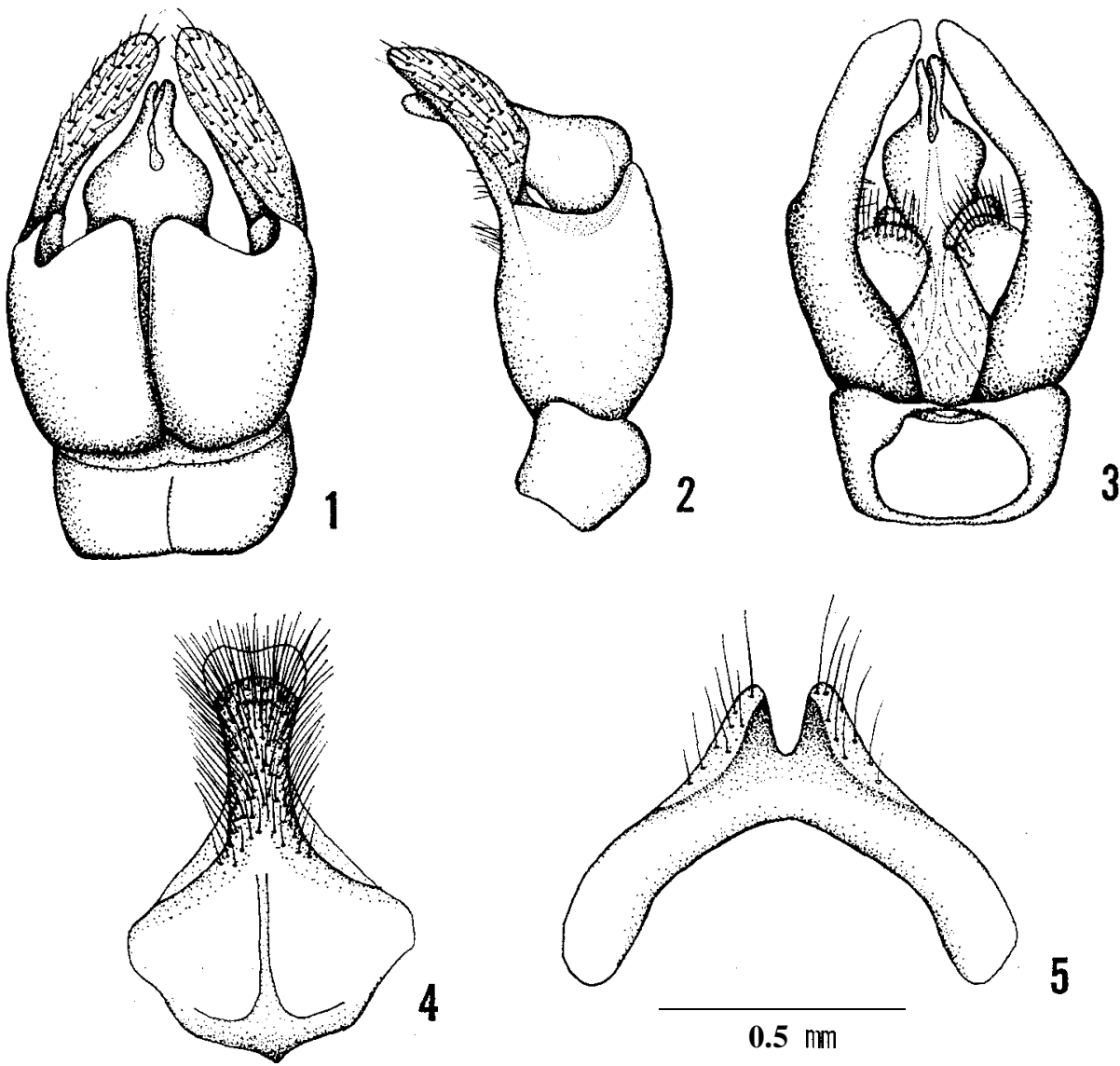

Figs. 1-5. Genital capsule and associated structures of Andrena (Micrandrena) hikosana Hirashima, 1: dorsal view of genital capsule, 2: lateral view of the same, 3: ventral view of the same, 4: 7th sternum, 5: 8th sternum.

Male : Length 5.5-6.0 mm.

Integumental color: flagellar segments 2-11 beneath ferruginous.

Pubescence: Hairs on body short, scanty, nearly uniformly dull white; head and thorax without brownish or blackish hairs ; hairs on clypeus short, sparse ; hairs on mesoscutum sparse; metasoma scanty of hairs; posterior margins of metasomal terga 2-4 each with an obscure, lateral fringe; posterior margins of metasomal sterna 2-4 without distinct, white fringes.

Structure: Process of labrum narrow, shiny, slightly emarginate apically; clypeus smooth and shiny with dense, distinct punctures; genal area narrower than eye seen in profile; flagellum 1 nearly as long as wide, about as long as 2, and as long as 3; mesoscutum very weakly tessellate, shiny, with strongly punctate; propodeal enclosure strongly wrinkled all over ; mesepisternum roughened; metasomal terga very weakly tessellate and shiny with fine punctures; posterior depressions of metasomal terga 2-3 well indicated; genitalia 


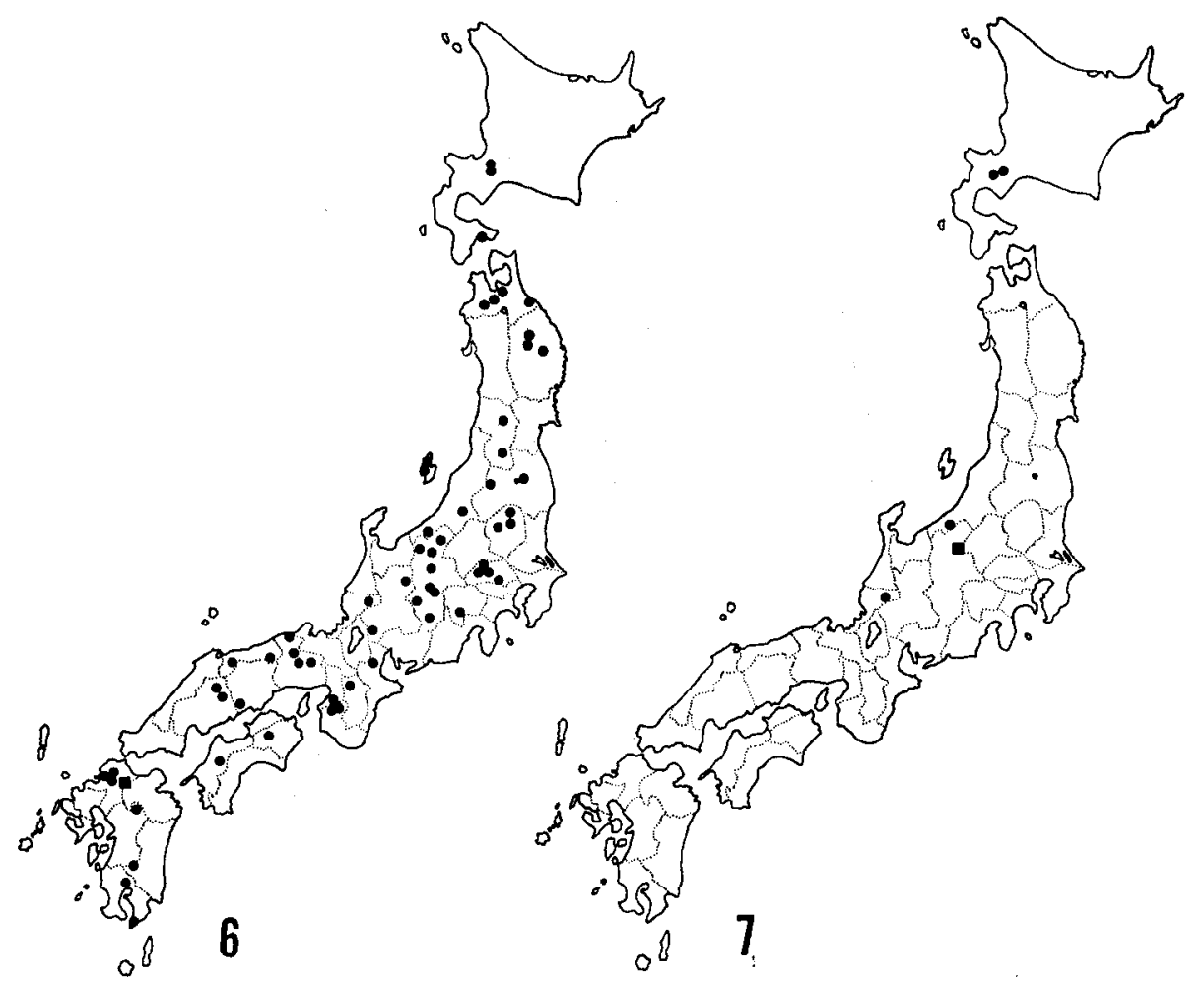

Figs. 6-7. Maps showing the distribution of Andrena (Micrandrena) hikosana Hirashima (6) and A. (Micrandrena) falsificissima Hirashima (7) based on the present study. A square indicates the type locality.

and associated structures as illustrated (Figs. S-12).

Distribution: Japan (Hokkaido, and central Honshu). (Fig. 7)

Floral records: Nine females have been taken from Angelica ursina Maxim., and 2 females from Aralia cordata Thunb. in Hokkaido by Prof. M. Munakata. Both plants belong to the Umbelliferae.

Flight records: Summer to autumnal species. Females have been taken from early August to early September, and males from late August to mid September.

Specimens examined: HOKKAIDO: 2 females, Kyogoku, Abuta-gun, 15. viii. 1961 (M. Munakata) ; same locality and collector as above, 3 females, 9. viii. 1963, 3 females, 19. viii. 1966, 1 female, 21. viii. 1966; 2 females, Wakikata, Shiribeshi, 17. viii. 1961 (M. Munakata). HONSHU : 2 females, Sasagamine, Niigata Pref., 11. viii. 1982 (K. Baba) ; 5 females and 1 male, Suwara, Ohno, Fukui Pref., 9. ix. 1973 (Y. Haneda) ; 2 females, Arashi, Ohno, Fukui Pref., 24. ix. 1971 (Y. Haneda); same locality and collector as above, 1 female and 2 males, 29. viii. 1973; 1 female, 23. viii. 1974; 1 male, Shimouchinami, Ohno Fukui Pref., 16. ix. 1974 (Y. Haneda). 

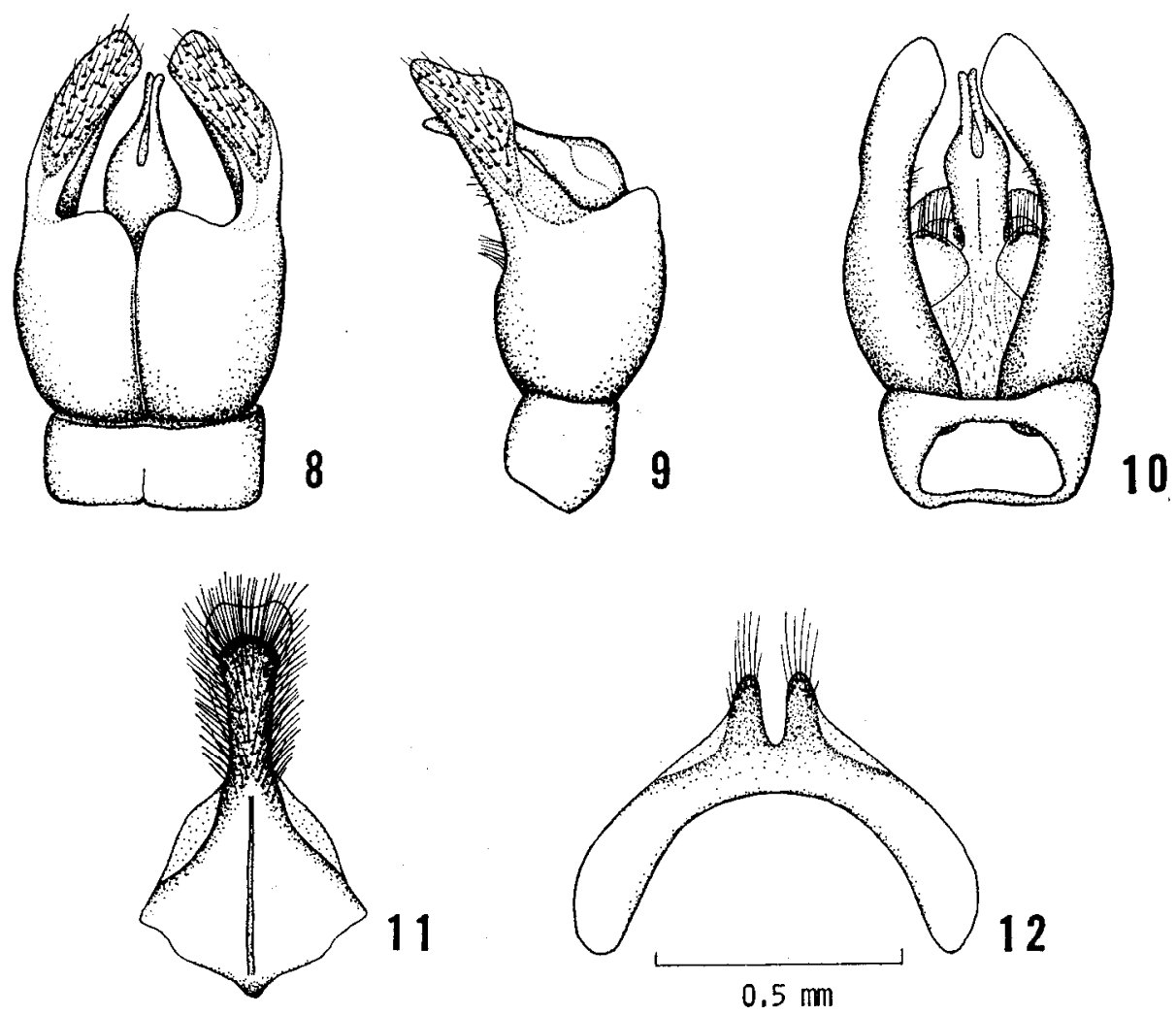

Figs. 8-12. Genital capsule and associated structures of Andrena(Micrandrena) falsificissima Hirashima, 8: dorsal view of genital capsule, 9: lateral view of the same, 10: ventral view of the same, 11: 7 th sternum, 12: 8 th sternum.

\section{Andrena (Micrandrena) komachi Hirashima}

Andrena (Micrandrena) komachi Hirashima, 1965, J. Fac. Agr., Kyushu Univ., 13: 469, female and male; Hirashima, 1966, J. Fac. Agr., Kyushu Univ., 14: 94 and 117.

This species primarily occur in western part of 'Japan. So far as I know, the distribution of this species in Hokkaido is restricted in southern part of the Oshima Peninsula. A closely resembled species, munakatai, n. sp., is distributed in northern part of Japan, Hokkaido and northern to central Honshu. The two species overlap each other from southern Hokkaido to central Honshu. This species is characterized by the $1 \mathrm{st}$ metasomal tergum nearly smooth and shiny with fine punctures, the posterior margins of the 2 nd to 4th metasomal sterna each with a complete fringe of dense, whitish hairs, and the male clypeus with, quite dense, silvery, downy hairs.

Distribution: Japan \{southern Hokkaido, Honshu, Shikoku, Kyushu, and Tsushima Is.). (Fig. 18) 

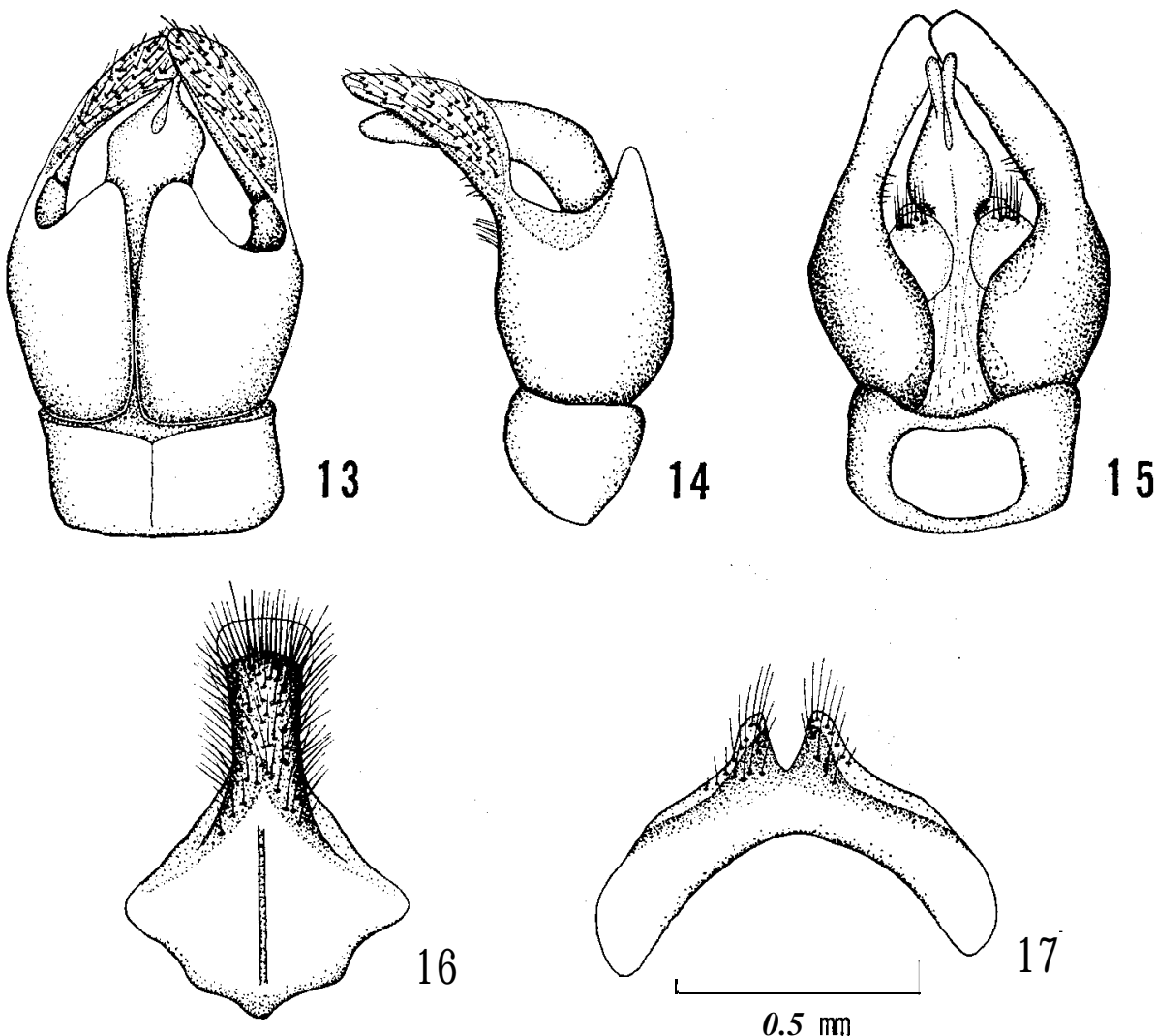

Figs. 13-17. Genital capsule and associated structures of Andrena(Micrandrena) komachi Hirashima, 13: dorsal view of genital capsule, 14: lateral view of the same, 15: ventral view of the same, 16: 7th sternum, 17: 8 th sternum.

Floral records: A total of 269 females and 16 males have been collected on 13 plants. The predominant plants are Potentilla, showing by the number of Potentilla visited, 220 females (81.8\%) and 4 males, against 49 females and 12 males. Rosaceae : Potentilla kleiniana subsp. anemonefolia Murata (44 females); $\boldsymbol{P}$. fragarioides var. major Maxim. (171 females and 4 males) ; $\boldsymbol{P}$. freyniana Bornum. (5 females); Fragaria ananassa Duch. (11 females) ; Rosa multiflora Thunb. (2 females). Cruciferae : Brassica napus L. (20 females and 11 males);Capsella bursa-pastoris Medic. (2 females) ; Rorippa indica Hieron (1 female). Leguminos. ae : Astragalus sinicus L. (6 females). Compositae : Taraxacum officinale Weber ( 3 females and 1 male); Ixeris stolonifera A. Gray (1 female and 1 male). Salicaceae: Salix sp. (1 female). Ranunculaceae: Ranunculus sp. (1 female).

Flight records: Females fly from late March to late May in Kyushu, and from early May to early June in Hokkaido. Males have been taken from mid to late April in Kyushu, and from early to mid May in Hokkaido.

Specimens examined: I have examined 305 females and 43 males collected 


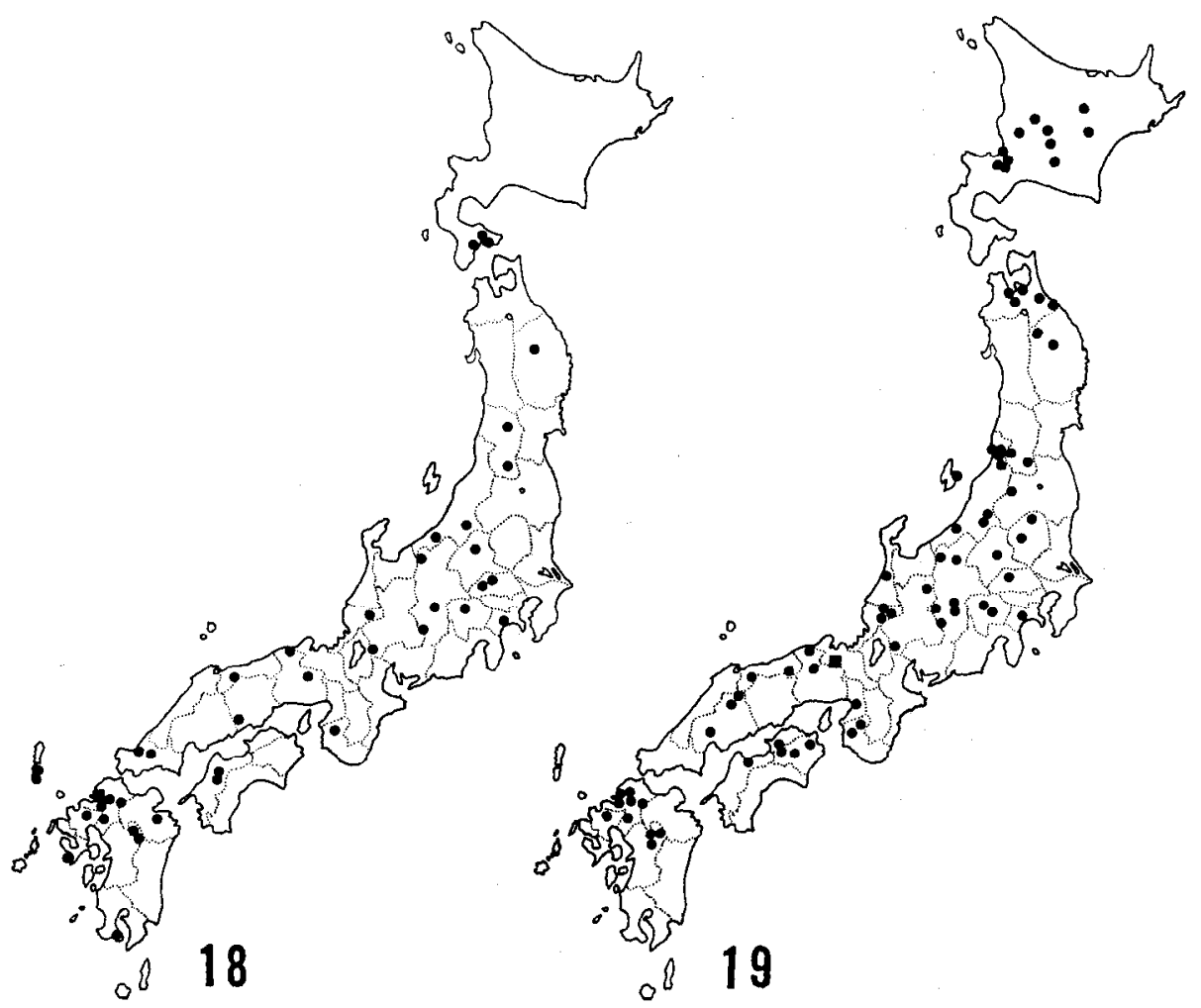

Figs. 18-19. Maps showing the distribution of Andrena (Micrandrena) komachi Hirashima (18) and A. (Micrandrena) sublevigafa Hirashima (19) based on the present study. A square indicates the type locality.

from Hokkaido, Honshu, Shikoku, Kyushu, and Tsushima Is. Some records from Hokkaido, Shikoku and Tsushima Is. are cited as follows: HOKKAIDO: 73 females, Narukawa, Nanae, 25. v. 1973 (M. Munakata) ; 2 males, Moheji, Kamiiso, 19. v. 1984 (0. Tadauchi). SHIKOKU: 1 female, Naose, near Kuma, Ehime Pref., 17. v. 1953 (T. Mohri) ; 1 female and 1 male, Ishii-mura near Matsuyama, Ehime Pref., 21. iv. 1960 (S. Hisamatsu). TSUSHIMA IS. : 1 female, Tsutsu-Kuneinaka, 27. v. 1930 (Esaki and Fujino); 4 females, Shimobaru, Izuhara, 20. iv. 1976 (0. Tadauchi).

\section{Andrena (Micrandrena) sublevigata Hirashima}

Andrena (Micrandrena) sublevigafa Hirashima, 1966, J. Fac. Agr., Kyushu Univ., 14: 91, female and male, and 95 and 117.

This species appears early in spring and abundantly visits the flowers of Brassicanapus L. and Salix spp.

Distribution: Japan (Hokkaido, Honshu, Sado Is., Shikoku, and Kyushu). (Fig. 19) 

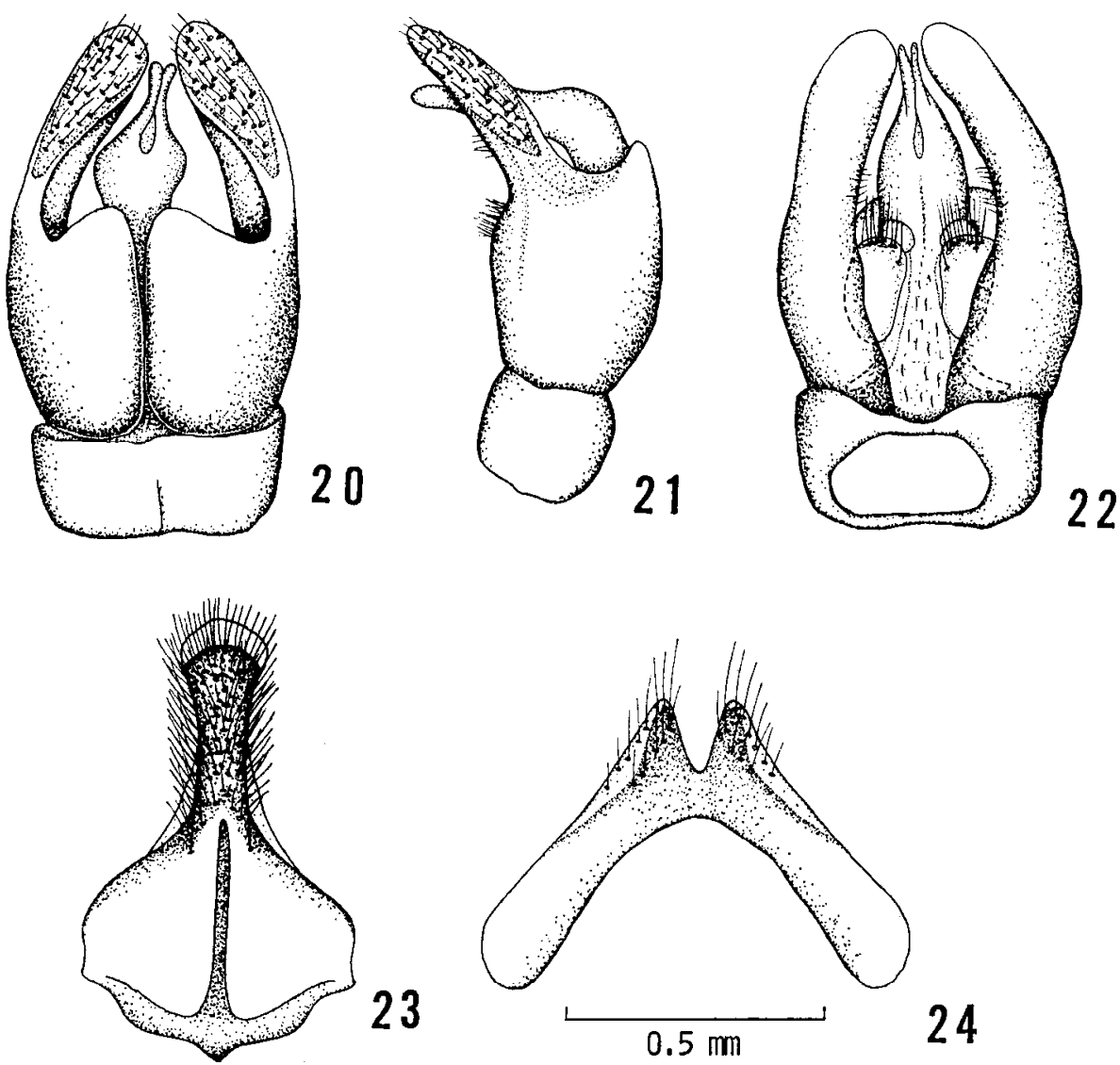

Figs. 20-24. Genital capsule and associated structures of Andrena(Micrandrena) sublevigata Hirashima, 20: dorsal view of genital capsule, 21: lateral view of the same, 22: ventral view of the same, 23: 7th sternum, 24: 8th sternum.

Floral records: This species has been collected on 37 plants. Cruciferae: Cardamine flexuosa With. (2 females) ; Brassica napus L. (504 females and 62 males) ; B. pekinensis Pupr. (18 females and 3 males) ; B.rapa var. glabra Kitam. (3 females) ; Barbarea orthoceras Ledeb. (3 females);Capsellabursa-pastoris Medic. (3 females). Ranunculaceae : Anemone flaccida Fr. Schm. (1 female) ; A. raddeana Regel (1 female). Salicaceae: Salix pet-susu Kim. (2 males) ; S. hultenii var. angustifolia Kim. (1 female) ; S. subfragilis And. (1 female) ; S. gracilistyla Miq. (111 females and 73 males) ; S. taraikensis Kimura (1 male) ; S. spp. (275 females and 235 males). Rosaceae :Pyrus pyrifolia var. culta Nakai (2 females) ; Prunus mume Sieb. et Zucc. (1 male) ; P. persica Batsch. (3 females) ; P. armeni. ana L. (1 female) ; P. yedoensis Matsum. (4 females) ; P. padus L.(1 female) ; $M a$ lus halliana Koehne (1 female); Fragaria ananassa Duch. (1 female) ; Potentilla kleiniana subsp. anemonefolia Murata (1 female) ; P. fragarioides var. major Maxim. 
(4 females) ;P. freyniana Borum. (2 females) ; Rosa multiflora Thunb. (1 female); Filipendula multijuga var. yezoensis Hara (1 female). Compositae :Taraxacum japonicum Koidz. (1 female);T. officinale Weber (82 females and 1 male) ; Lapsana apogonoides Maxim. (4 females) ; Petasites japonicus subsp. giganteus Kitam. (2 males). Serophulariaceae : Veronica didyma var. lilacina Yamaz. (1 male). Caryo. phyllaceae : Stellaria media Villars (1 female). Caprifoliaceae :Lonicera gracilipes Miq. (1 female). Labiatae: Glechoma hederacea var. grandis Kudo (1 female). Leguminosae : Astragalus sinicus L. (2 females). Liliaceae :Gagealutea KerGawl. (6 females).

Flight records: Females have been taken from early March to mid May in Kyushu and late April to early June in Hokkaido. Males fly from early March to early May in Kyushu and late April to early June in Hokkaido.

Specimens examined: I have examined a total of 1,172 females and 561 males from Hokkaido, Honshu, Sado Is., Shikoku, and Kyushu. Some records from Sado Is. and Shikoku are cited as follows: SADO IS. : 2 females, Suizu, Ryozu, 10. v. 1980 (K. Baba). SHIKOKU: 1 female, Ikeda, Tokushima Pref., 1. v. 1975 (0. Tadauchi) ; 1 male, Komi, Ichiu, Tokushima Pref., 17. iv. 1976 (0. Tadauchi) ; 1 female, Myodomachi, Tokushima Pref., 11. iv. 1960 (T. Kobayashi) ; 1 female and 12 males, Saita, Kagawa Pref., 5. iv. 1976 (S. Ikudome) ; 3 females and 1 male, Nakano, Saijo, Ehime Pref., 18. iv. 1975 (0. Tadauchi).

\section{Andrena (Micrandrena) brassicae Hirashima}

Andrena (Micrandrena) brassicae Hirashima, 1957, Mushi, 30: 52, female and male; Hirashima, 1965, J. Fac. Agr., Kyushu Univ., 13: 464, female and male; Hirashima, 1966, J. Fac. Agr., Kyushu Univ., 14: 95 and 117; Kim and Kim, 1983, Kor. J. Ent., 13: 7.

This is one of the most common species of Micrandrena in Japan. It has two generations a year. Some seasonal differences are found in male as observed in A. (Micrandrena) minutula (Kirby) in Europe. The first generation is characterized by having the brownish hairs on the head and the thorax (whitish in the 2nd), the mesoscutum tessellate (nearly smooth and shiny to weakly tessellate in the 2nd), and the 1st metasomal tergum weakly tessellate, impunctate (nearly smooth and shiny with small punctures in the 2nd).

It occurs in all over Japan and prefers to visit the flowers of Brassicanapus L. (western part of Japan), Taraxacum officinale Weber (northern part of Japan) in the 1st generation, and the Umbelliferae in the 2nd.

Distribution: Japan (Hokkaido, Honshu, Sado Is., Shikoku, Kyushu, Tsushima Is., and Yakushima Is.) (Fig, 30), and Korea.

Floral records: This species has been collected on 83 plants. Cruciferae : Brassica napus L. (2,383 females and 6 males) ; B. oleracea var. capitata L. (6 females) ; B. rapa var. glabra Kitam. (16 females) ; B. pekinensis Pupr. (1 female and 2 males) ; Rorippaindica Hieron (2 females) ; R. sylvestris Besser (32 females) ; R. islandica Boras (1 female) ; R. nikkoensis Hara (4 females) ; Barbarea vulgaris R. Br. (8 females) ; B. orthoceras Ledeb. (109 females) ; Raphanus sativus var. hortensis Backer (3 females) ; Capsella bursa-pastoris Medic. (4 females) ; Cardamine leucantha 0. E. Schulz (3 females) ; Arabis glabra Bernh. (1 female). 

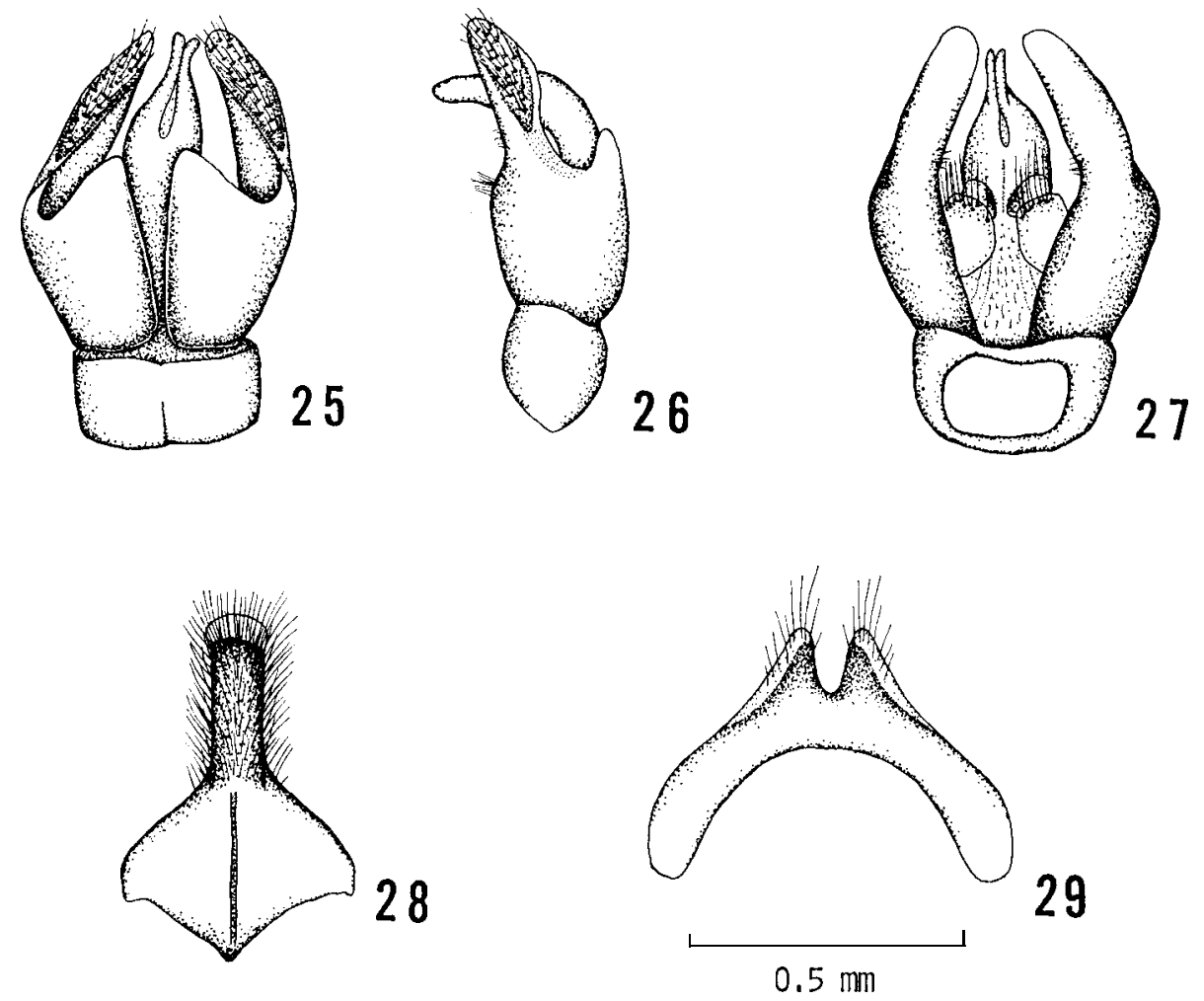

Figs. 25-29. Genital capsule and associated structures of Andrena(Micrandrena) brassicae Hirashima, 25: dorsal view of genital capsule, 26: lateral view of the same, 27: ventral view of the same, 28: 7th sternum, 29: 8 th sternum.

Rosaceae: Fragaria ananassa Duch. (3 females) ; Prunusarmeniaca L. (16 females) ; P. mume Sieb. et Zucc. (3 females) ; P. yedoensis Matsum. (19 females) ; P. salicina Lindl. (4 females) ; P. persica Batsch. (5 females); Malus halliana Koehne (60 females) ; M. pumilla Mill. (46 females); Pyrus pyrifolia var. culta Nakai (48 females) ; Photinia glabra Maxim. (1 female) ; Potentilla kleiniana subsp. anemonefoZia Murata (4 females) ; P. recta L. (2 males); P. fragarioides var. major Maxim. (9 females) ; P. fruticosa L. (2 females) ; Kerria japonica DC. (1 female) ; Rubus hirsutus Thunb. (2 females) ; Spiraea cantoniensis Lour. (3 females) ; S. betulifolia Pall. (3 females) ; S. salicifolia L. (3 females) ; Aruncus dioicus var. tenuifolius Hara (5 females) ; Sorbus alnifolia C. Koch (3 females) ;Chaenomeles japonica Lindl. (1 female). Leguminosae: Triforium pratense L. (2 males) ; T. repens L. (4 females and 1 male);Astragalus sinicus L. (2 females). Caryophyllaceae :Stellaria media Villars (1 female);Cerastium fischerianum Ser. (6 females). Salicaceae:Salix hultenii var. angustifolia Kimura (15 females); S. taraikensis Kimura (17 females) ; S. gracilistyla Miq. (2 females) ; S. matsudana forma tortuosa Rehd. (1 female); S. spp. (48 females and 3 males). Compositae : Petasites japonicus 


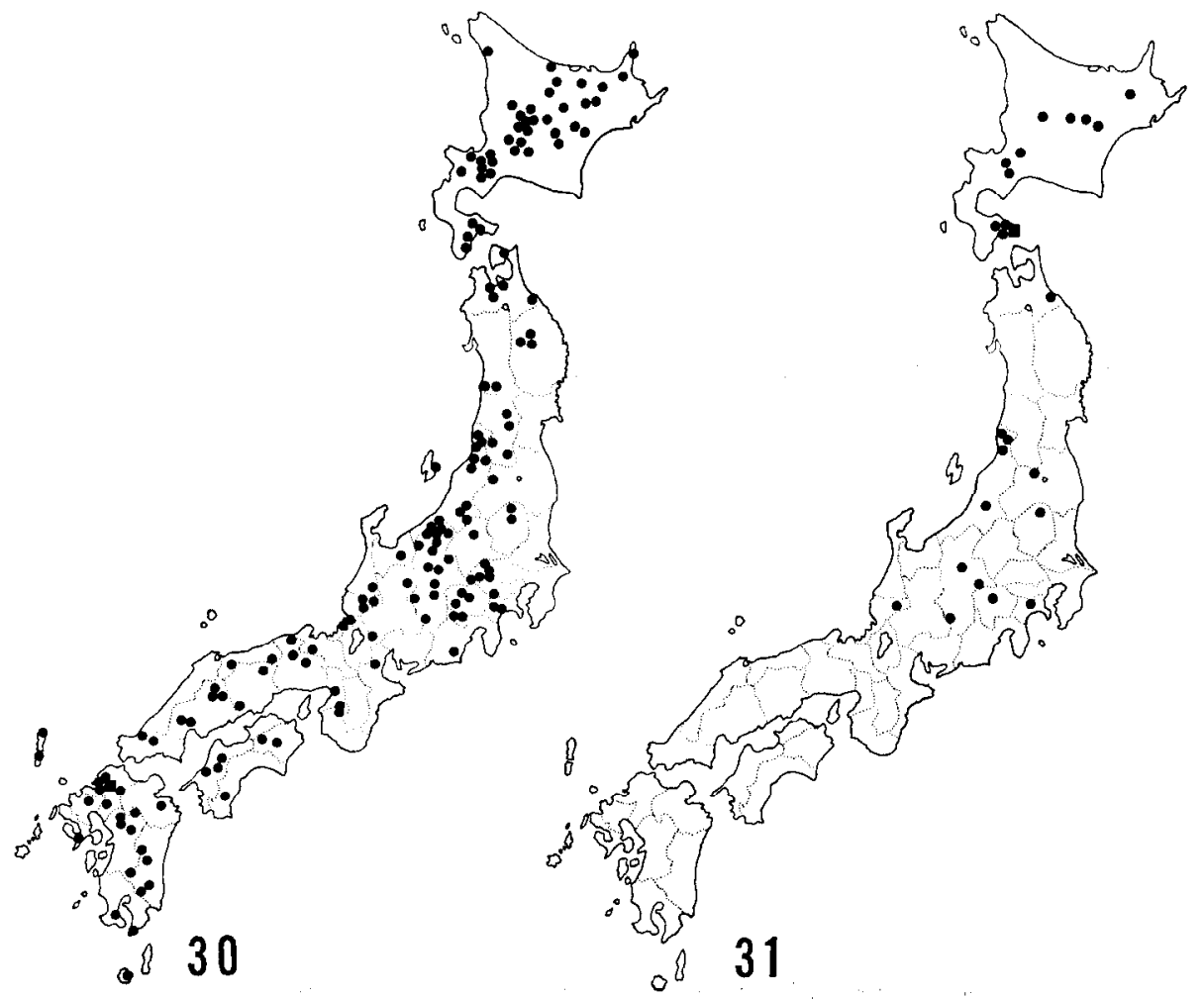

Figs. 30-31. Maps showing the distribution of Andrena (Micrandrena) brassicae Hirashima (30) and A. (Micrandrena) munakatai, new species (31) based on the present study. A square indicates the type locality.

subsp. giganteus Kitam. (6 females and 5 males) ;Cirsium sp. (2 females) ; Aster glehni Fr. Schm. (4 females and 1 male) ; Picris hieracioides subsp. japonica Krylr. (2 females) ; Ixeris stolonifera A. Gray (3 females) ; I. dentata Nakai (2 females) ; Taraxacum officinale Weber (269 females and 8 males) ; T. japonicum Koidz. (7 females) ; Erigeron annuus Pers. (4 females and 15 males) ; Chrysanthemum leucanthemum L. (5 females); Sonchus brachyotus DC. (1 male); Anaphalis margaritacea Benth. et Hook. (2 females and 1 male) ; Lapsana apogonoides Maxim. (2 females) ; Hypochoeris radicata L. (1 male). Liliaceae: Allium fistulosum L. (2 females). Scrophulariaceae :Veronica persica Poir. (1 male). Ranunculaceae :Cimicifuga simplex Wormsk. (12 females) ; Anemone raddeana Regel (2 females) ; Justicia procumbens var. leucantha Honda (3 females) ; Ranunculus sp. (1 female). Umbelliferae:Heracleum dulce Fisch. (17 females and 1 male) ; H. moellendorffi Hance (1 female) ; Sium sisarum L. (2 females) ; Aralia cordata Thunb. (3 females and 1 male) ; Angelica anomala Lallem. (8 females) ; A. ursina Maxim. (53 females and 10 males) ; Anthriscus sylvestris subsp. aemula Kitam. (109 females) ; Petroselium sativum Hoffm. (14 females and 1 male) ; Daucus carota L. (4 females) ;Torilis japonica DC. (10 females). Fagaceae : Castanea crenata Sieb. et Zucc. (7 females). 
Cornaceae :Cornus controversa Hemsl. (1 female). Guttiferae :Hypericum erectum Thunb. (1 female and 2 males). Ericaceae : Pieris japonica D. Don. (1 female); Rhododendron sp. (1 female). Caprifoliaceae : Weigela hortensis K. Koch (1 female). Polygonaceae :Polygonum sachalinense Fr. Schmidt. (2 females). Berberidaceae : Epimedium grandiflorum var. thunbergianum Nakai (1 female).

Flight records: Two generations a year. In Kyushu females of the first generation have been taken from early March to late April, and those of the 2nd from late May to early August. Males fly from late March to late April for the 1st generation, and from late May to early June for the 2nd.

Specimens examined: I have examined 3,354 females and 220 males from Hokkaido, Honshu, Sado Is., Shikoku, Kyushu, Tsushima Is. and Yakushima Is. Some records from Sado Is., Shikoku, Tsushima Is., and Yakushima Is. are cited as follows: SADO IS.: 10 females, Suizu, Ryozu, 10. v. 1980 (K. Baba). SHIKOKU: 39 females, Ikeda, Tokushima Pref., 1. v. 1975 (0. Tadauchi) ; 6 females, Komi, Ichiu, Tokushima Pref., 17. iv. 1976 (0. Tadauchi) ; 43 females, Tanono, Taisho, Kochi Pref., 16. iv. 1976 (0. Tadauchi) ; 88 females, Kaminada, Futami, Ehime Pref., 16. iv. 1975 (0. Tadauchi) ; 2 females and 3 males, Ochiai, Kuma, Ehime Pref., 15. iv. 1976 (0. Tadauchi) ; 1 male, Omogo-kei, Ehime Pref., 3-4.v.1958 (Y. Miyatake). TSUSHIMA IS.: 66 females, Shimobaru, Izuhara, 20. iv. 1976 (0. Tadauchi) ; 2 females, Hitakatsu-Nishidomari-Gongenyama, 12. iv. 1941 (T. Shirozu) ; 4 females and 4 males, Izuhara-Ariakeyama, 9. iv. 1941 (T. Shirozu). YAKUSHIMA IS. : 3 males, Arakawa-Kosugidani, 28. iv. 1975 (K. Kanmiya).

\section{Andrena (Micrandrena) munakatai, new species}

This is a sibling species of Andrena komachi Hirashima and also similar to the European Andrenaalfkenelloides Warncke. But, it is separable from komachi by the 1st metasomal tergum tessellate and impunctate, the metasomal sterna without dense, white fringes (clearly observed in male) and the male silvery hairs on the clypeus sparser and shorter. It is also separated from alfkenelloides by the head without blackish hairs, the mesoscutum shiny and smooth with stronger punctures, and the propodeal enclosure more wrinkled. This species occurs in Hokkaido and northern to central Honshu. It predominantly visits the flowers of Potentilla as komachi.

Female : Length 6. 0-6.5 mm.

Integumental color: Flagellar segments 3-10 beneath reddish brown ; posterior margins of metasomal terga narrowly reddish brown.

Pubescence: Hairs on head and thorax short, on head whitish, on vertex and thorax dull, whitish; metasomal tergum 1 nearly free of hairs; posterior margins of metasomal terga 2-3 with lateral fringes of dense, appressed, white hairs; caudal fimbria pale brownish; sterna 2-5 with apical fringes of dull, white hairs, which are less distinct (sparser and shorter) than in komachi.

Structure: Process of labrum large, rectangular; clypeus well convex, den- 
sely tessellate, scattered with weak punctures, dull; facial fovea with lower end reaching basal margin of clypeus; genal area narrower than eye seen in profile; apical transverse groove of pronotum not notched in the middle; mesoscutum weakly tessellate and shiny with small, dense, a little roughened punctures; scutellum nearly smooth, shiny; propodeal enclosure large, well indicated, strongly wrinkled all over ; mesepisternum shagreened anteriorly, densely tessellate posteriorly ; metasomal tergum 1 densely tessellate, impunctate (nearly smooth and shiny with scattered with fine punctures in komachi); tergum 2 and following terga distinctly tessellate ; posterior depressions of terga 2-4 narrower than in komachi.

\section{Male : Length 6.0-6.5 mm.}

Integumental color: Flagellar segments 3-11 beneath slightly reddish brown.

Pubescence: Hairs on head and thorax white ; hairs on clypeus silvery white, dense, but shorter and sparser than in komachi; metasomal terga 2-3 with white, lateral fringes, tergum 4 nearly without lateral fringe, tergum 6 with sparse, whitish hairs (slightly yellowish in komachi) ; metasomal sterna 2-5 without apical white fringes as in komachi.

Structure: Clypeus with apical half weakly roughened, weakly shiny with weak, roughened punctures; flagellum 1 longer than 2 , and as long as 3 ; genal area narrower than eye seen in propfile; mesoscutum weakly tessellate with dense, roughened punctures ; metasomal tergum 1 tessellate, impunctate (metasomal tergum 1 nearly smooth with fine punctures in komachi) ; posterior depressions of metasomal terga weakly indicated; genitalia and associated structures as illustrated (Figs. 32-36).

Distribution: Japan (Hokkaido, northern and central Honshu). (Fig. 31)

Floral records,: A total of 156 females and 17 males have been collected on 12 plants. Potentilla flowers are predominant (89.7 \% in female) as komachi. Rosaceae : Potentilla fragarioides var. major Maxim. (101 females and 7 males) ; $\mathbf{P}$. freyniana Borum (39 females) ; P. dickinsii Fr. et Sav. (5 males) ; Fragaria yezo. ensis Hara (1 male) ;Waldsteiniaternata Fritsch (1 female). Compositae :Taraxacum officinale Weber ( 7 females and 3 males) ; Ixeris stolonifera A. Gray (1 male) ; Chrysanthemum frutescens L. (2 females). Cruciferae: Brassicanapus L. (2 females). Umbelliferae : Angelica anomala Lallem. (2 females). Salicaceae :Salix integra Thunb. (1 female). Caryophyllaceae :Cerastium sp. (1 female).

Flight records: Females fly from late April to late June in Hokkaido, and from mid April to mid June in Honshu. Males have been taken from early May to mid June in Hokkaido and early to late May in Honshu.

Type material: Holotype female (Type No. 2509, Kyushu Univ.), Shirikishinai, Kamedagun, Hokkaido, 17. v. 1964 (M. Munakata). Paratypes: HOKKAIDO: 15 females, Kyushu Univ. Forests, Ashoro, 25. v. 1984 (0. Tadauchi) ; same locality and collector as above, 1 female, 6. vi. 1984; 1 female, 22. vi. 1984; 1 male, Tokachimitsumata, Kamishihoro, 12. vi, 1984 (0. Tadauchi) ; same locality and collector as holotype: 1 male, 6. v. 1964; 5 females and 1 male, 17. v. 1964, 1 male, 7. vi. 1964, 1 female, 12. vi. 1964; 1 male, Narukawa, Nanae, 15. v. 1973 (M. Munakata). HONSHU: 2 females, Urabandai, Fukushima Pref., 

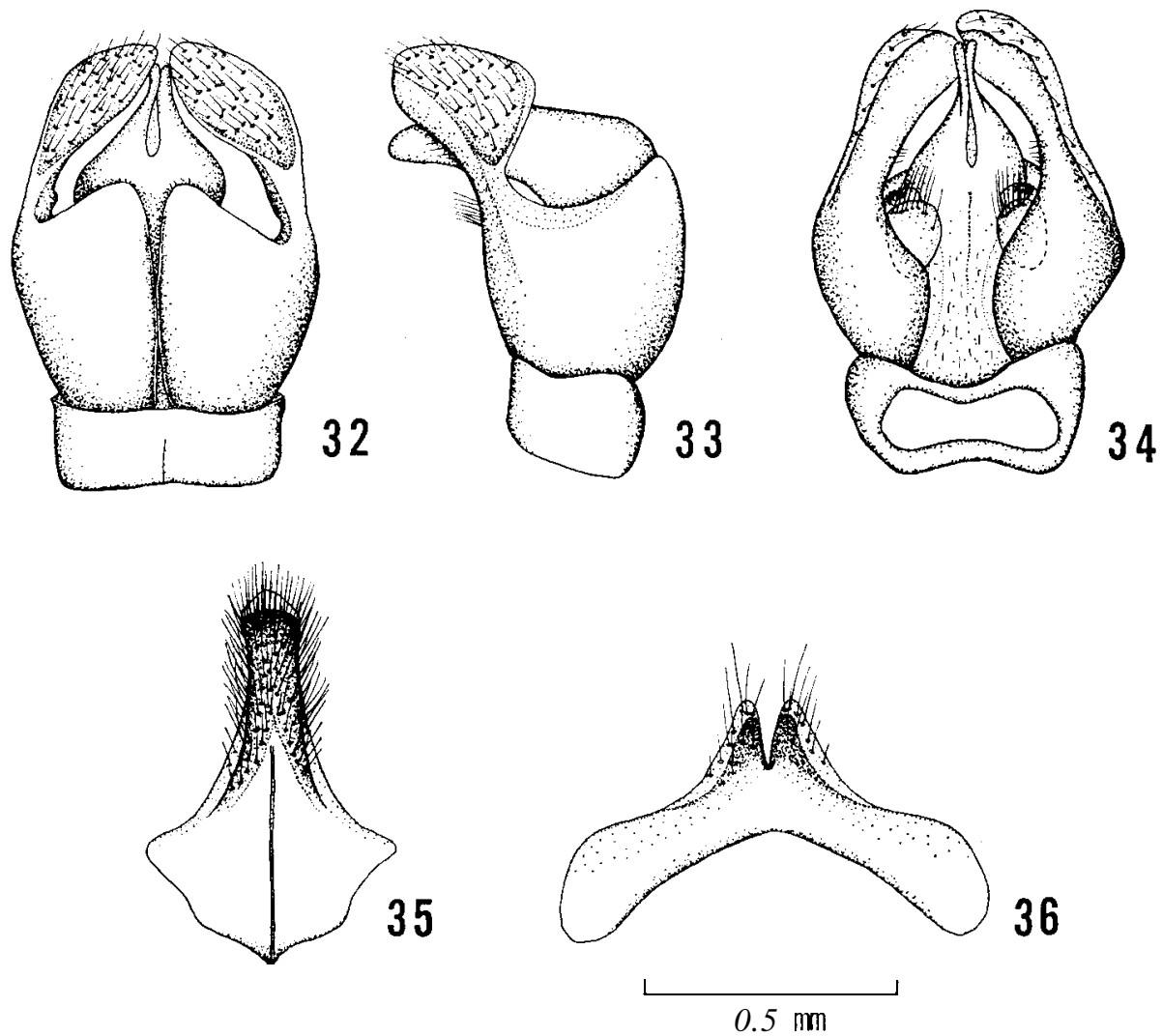

Figs. 32-36. Genital capsule and associated structures of Andrena(Micrandrena) munakatai, new species, 32: dorsal view of genital capsule, 33: lateral view of the same, 34: ventral view of the same, 35: 7 th sternum, 36 : 8th sternum.

16-17. v. 1957 (R. Ishikawa) ; 4 males, Utsukushigahara, 1500 m, Nagano Pref., 6. v. 1961 (Y. Hirashima)

Specimens examined other than the types: I have examined a total of $64 \mathrm{fe}-$ males and 19 males including the type materials. Some records are cited as follows: HOKKAIDO: 1 female, Kussharoko, Teshikaga, 26. v. 1984 (0. Tadauchi) ; 3 females, Ashorobuto, Ashoro, 22. v. 1957 (M. Takahashi) ; same locality and collector as above, 1 female, 23. v. 1957, 1 female, 28. v. 1957; 1 female, Metou, Ashoro, 19. vi. 1957 (M. Takahashi) ; 1 female, Otarunai, 7. vi. 1973 (H. Fukuda) ; 3 females, Hakodateyama, Hakodate, 22. iv. 1959 (M. Munakata). HONSHU: 1 female, Hachinohe, Aomori Pref., 20. v. 1960 (A. Fukuda) ;1 female, Moriko, Nasu, Tochigi Pref., 22. v. 1975 (0. Tadauchi) ; 1 male, Takane, Niigata Pref., 13. v. 1982 (K. Baba) ; 2 females, Miomote, Niigata Pref., 28. v. 1980 (K. Baba) ; 1 male, Kurokawa, Niigata Pref., 5. v. 1983 (K. Baba); 4 females, Oyanohara, Mt. Shirouma, Nagano Pref., 15. v. 1976 (0. Tadauchi); 1 female and 1 male, Sanjiro, Utsukushigahara, Nagano Pref., 27. v. 1957 (R. 
Ishikawa) ; 2 females, Mt. Yatsugatake, Chino, Nagano Pref., 20. vi. 1962 (Y. Maeta).

Type depository: The type is preserved in the collection of the Entomological Laboratory, Faculty of Agriculture, Kyushu University.

The specific name is dedicated to Prof. Meiyo Munakata of Hakodate College, Hokkaido Univ. of Education, who has long studied the bee fauna in the Oshima Peninsula, southern Hokkaido.

\section{Andrena (Micrandrena) hanedai, new species}

This is a unique species in our fauna. The female of this species is somewhat similar to Andrena falsificissima Hirashima, but is easily distinguished by the combination of the following characters: the hairs on the head and thorax yellowish to yellowish brown, the clypeus strongly convex, the mesoscutum with close, roughened, strong punctures, the propodeal enclosure granulate apically, the dorsal face of the propodeum shagreened and not roughened, and the 1st metasomal tergum very weakly tessellate, shiny, impunctate. The male of this species closely resembles that A. brassicae in the 2 nd generation. But it is separable by having the propodeal enclosure not well defined, granulate apically, the 2nd to 3rd metasomal terga with poorly developed lateral fringes, and the head and thorax with yellowish hairs. It is distributed in Hokkaido and central Honshu. The flying season is from August to September.

Female : Length 5.5-6.5 mm.

Integumental color: Flagellar segments $3-10$ beneath slightly reddish brown ; posterior margins of metasomal terga narrowly reddish brown.

Pubescence: Hairs on head and thorax yellowish to yellowish brown, sparse; facial fovea golden above, yellowish white below; tibia1 scopa composed of more or less loose, yellowish hairs; metasomal tergum 1 free of hairs; posterior margins of metasomal terga 2-3 with lateral fringes poorly developed; caudal fimbria pale brownish; metasomal sterna without distinct marginal fringes.

Structure: Process of labrum small, nearly as broad as long, slightly round apically ; clypeus strongly convex, weakly tessellate with sparse, weak punctures; facial fovea with upper end occupying slightly more than one half of postocellar distance, with lower end reaching basal margin of clypeus; genal area narrower than eye seen in profile; apical transverse groove of pronotum not notched in the middle; mesoscutum roughened with close, roughened, strong punctures; scutellum nearly smooth, shiny, with sparse punctures; propodeal enclosure large, not well indicated, wrinkled basally, granulate apically; mesepisternum shagreened anteriorly, densely tessellate posteriorly ; metasomal tergum 1 very weakly tessellate, shiny, impunctate ; posterior depressions of metasomal terga 2-4 weakly indicated.

Male : Length 5.0-5.5 mm. 

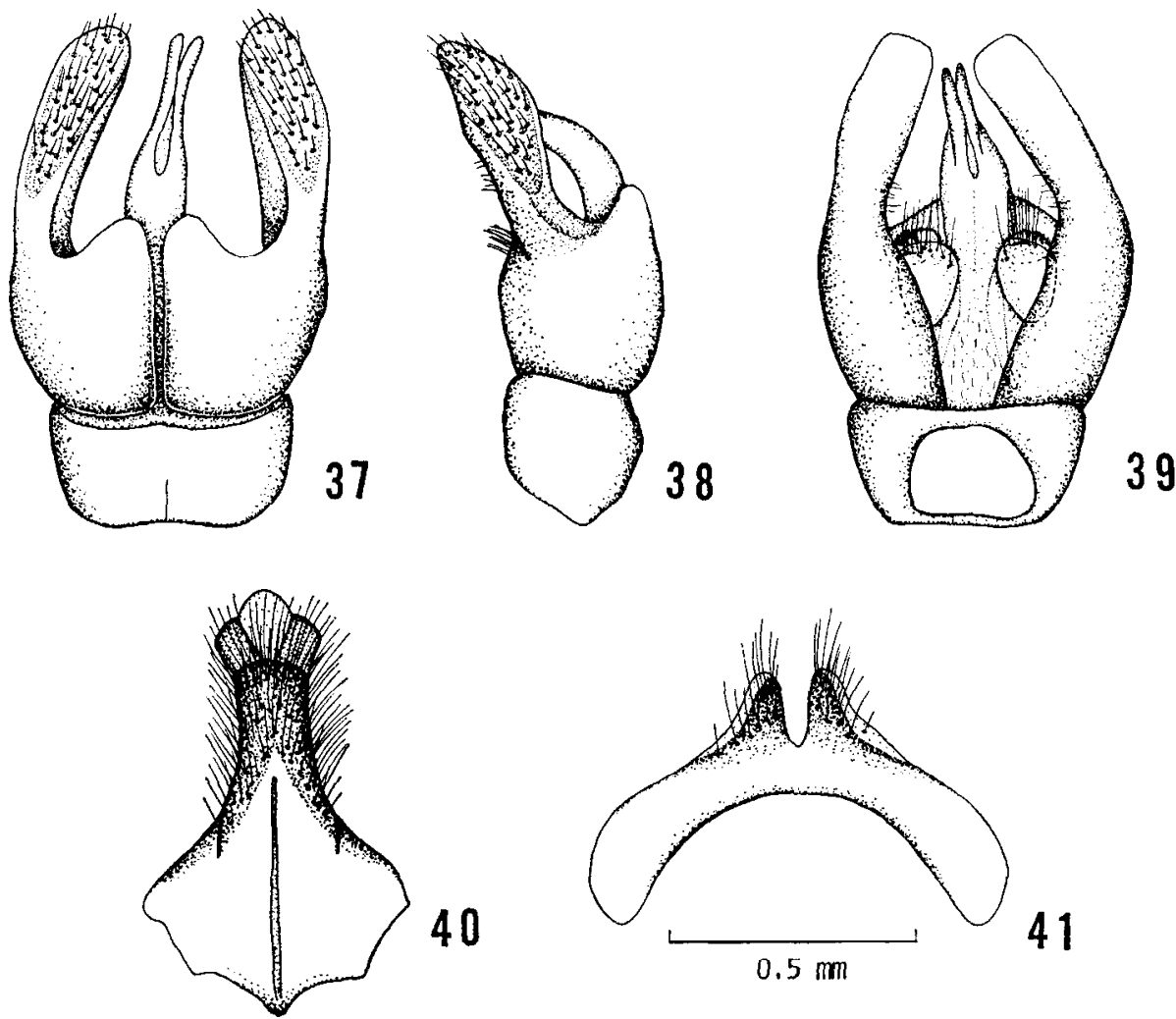

Figs. 37-41. Genital capsule and associated structures of Andrena(Micrandrena) hanedai, new species, 37: dorsal view of genital capsule, 38: lateral view of the same, 39: ventral view of the same, 40: 7th sternum, 41: 8th sternum.

Integumental color: Flagellar segments 3-11 beneath brownish.

Pubescence: Hairs on head and thorax yellowish; hairs on clypeus pale yellowish, very sparse; metasomal terga 2-4 with lateral fringes of subappressed, white hairs, poorly developed; metasomal tergum 6 with sparse, pale yellowish hairs; metasomal sterna 2-5 without apical, distinct, white fringes.

Structure: Clypeus strongly convex nearly smooth, scattered with weak punctures, except for lateral margins tessellated; flagellum 1 longer than 2 , and as long as 3; genal area narrower than eye seen in profile; mesoscutum weakly tessellate, weakly shiny with more or less strong, roughened punctures; metasomal tergum 1 smooth, shiny, with fine punctures, following metasomal terga weakly tessellate basally, smooth and shiny with fine punctures apically ; posterior depressions of metasomal terga 2-4 strongly indicated; genitalia and associated structures as illustrated (Figs. 37-41).

Distribution: Japan (Hokkaido and central Honshu). (Fig. 42)

Floral records: A total of 26 females have been collected on 7 plants in 


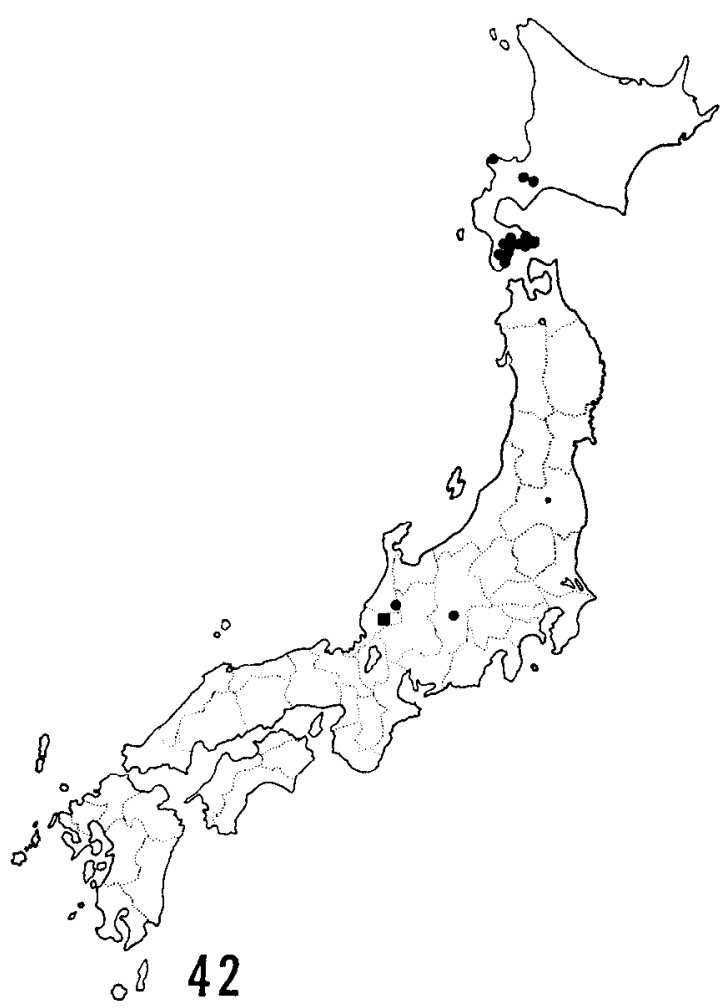

Fig. 42. Map showing the distribution of Andrena(Micrandrena) hanedai, new species based on the present study. A square indicates the type locality.

Hokkaido by Prof. M. Munakata. Umbelliferae: Angelica ursina Maxim. (15 females) ; A. edulis Miyabe (2 females) ; Aralia cordata Thunb. (3 females). Compositae : Aster glehni Fr. Schm. (1 female) ; Erigeron annuus Pers.(1 female). Geraniaceae :Geranium thunbergii Sieb. et Zucc. (3 females). Saxifragaceae : Hydrangea macrophylla var. megacarpa Ohwi (1 female).

Flight records: Females have been taken from late August to late September in Honshu, and from early August to early October in Hokkaido. Males have been collected in late August in Honshu.

Type material: Holotype female (Type No. 2510, Kyushu Univ.), Shimouchinami, Ohno, Fukui Pref., 25. viii. 1974 (Y. Haneda). Paratypes: Same locality and collector as holotype: 1 female and 1 male, 24 . viii. 1967, 1 female, 29. ix. 1968, 2 females, 23. ix. 1972, 1 female and 1 male, 23. viii. 1973, 2 females and 2 males, 25. viii. 1974, 1 female, 29. viii. 1974, 1 female, 16. ix. 1974; 2 females and 2 males, Koike, Ohno, Fukui Pref. (Y. Haneda) ; 1 female, same locality and collector as above, 31. viii. 1973; 1 female and 1 male, Arashi, 23. viii. 1974 (Y. Haneda); same locality and collector as above, 30. viii. 1974; 6 females, Suwara, Ohno, Fukui Pref., 9. ix. 1973 (Y. Haneda). 
Specimens examined other than the types: HOKKAIDO: 1 female, Usubetsu, near Jozankei, 21. ix. 1973 (H. Fukuda) ; 1 female, Otarunai, near Jozankei, 6. ix. 1973 (H. Fukuda) ; 1 female, Horomui, Shakotan, 8. viii. 1968 (M. Munakata) ; 1 female, Yagigawa, Minamikayabe, Oshima, 27. viii. 1982 (T. Onodera); 1 female, Shirikishinai, Oshima, 21. ix. 1962 (M. Munakata) ; 1 female, Menagawa Rindo, Shirikishinai, Oshima, 3. x. 1976 (A. Taguchi) ; 2 females, Yachiyama, Hakodate, 29. viii. 1982 (H. Akiyama) ; 1 female, Hachiro-numa, Ohno, Oshima, 3. x. 1982 (M. Komaki) ; 1 female, Nakayama Pass, Oshima, 1. viii. 1978 (H. Narumi) ; 3 females, Kamekawa, Kikonai, Oshima, 8. ix. 1981 (K. Kobayashi) ; 1 female, Sumikawa Rindo, Fukushima, Oshima, 20. viii. 1980 (H. Akagashi) ; 5 females, Mt. Daisengen, Oshima, 21. viii. 1980 (M. Munakata) ; 1 female, Oshima-Fukushima, 18. viii. 1978 (H. Tanabe); 1 female, same locality and collector as above, 5. ix. 1978. HONSHU: 1 female, Onnazawa, Ina, Nagano Pref., 21. viii. 1962 (Y. Maeta); 1 female, Iwama Spa, Mt. Haku, 23. viii. 1960 (I. Togashi).

Type depository: The type is preserved in the collection of the Entomological Laboratory, Faculty of Agriculture, Kyushu University.

The specific name is dedicated to Mr. Yoshito Haneda, who has kindly offered valuable bee specimens collected by him in Fukui Pref., central Honshu. 